\title{
DECIDUOUS TOOTH ERUPTION
}

\author{
BY \\ FRANK FALKNER* \\ From the Institute of Child Health and the Child Study Centre, University of London
}

(RECEIVED FOR PUBLICATION MAY 15, 1957)

There is little information concerning deciduous tooth eruption pertaining to children of the United Kingdom and Europe. Therefore, data on children from the current longitudinal growth study at the Child Study Centre, London, were examined. For details of this sample, method of recruitment, and investigations carried out, etc., reference may be made to Moore, Hindley and Falkner (1954). Briefly, this unselected sample of approximately 200 children consists of the same 'healthy' children regularly and periodically seen and drawn from an area in London.

The children are seen at the ages of 4 weeks ( \pm 2 days), 13, 26, 39 weeks, 1 year, 18 months ( \pm 7 days), 2 years and thereafter yearly ( \pm 14 days). The state of dentition is noted at each visit and for the purpose of this paper the total number of erupted teeth is given. The definition of eruption used is that stage when part of the crown of the tooth has pierced the gum (Robinow, Richards and Anderson, 1942; Doering and Allen, 1942; Falkner, 1955, 1957a).

\section{Distribution}

Table 1 gives the mean numbers of erupted deciduous teeth present at each age (correct to one decimal place). Boys and girls are separated.

* Markle Scholar in Medical Science. Now at the Department of Pediatrics, University of Louisville School of Medicine, Louisville, Kentucky, U.S.A.
There is a great variation in the number of teeth $\vec{P}$ being erupted between each age level after eruption has begun, and the distribution curves showing totafs number of erupted teeth are skewed to the right especially during the period of maximum eruption? activity, i.e., 39 weeks to 18 months (Doering and Allen, 1942). Hence, standard deviations are no presented as data, and for the range of 'likelys normality', percentiles are given for boys and girlsos combined.

Table 2 shows the increments of the number of teeth erupting between the various ages.

Only those children seen at the beginning and? end of each age period may be included in these calculations, for not every child is able to be present for every planned examination. It was obviousisyo convenient to use the unit of 13 weeks (approximatey three months) as the constant incremental perisid so as to compare rates of eruptions. Some of periods are not 13 weeks. The period, for example $\overline{5}$ between the examinations at 4 weeks and 13 weeks is only nine weeks, and this figure has been adjusted to bring it to a 13 weeks' increment (adjusted incre ment). This is not entirely permissible for if presumes a straight line rate of eruption which may not be the case. However, since the incrementat periods are close together in time the adjustments are felt to be justified for this purpose.

The incremental distribution curve of erupted

TABLE 1

MEAN NUMBER OF ERUPTED TEETH AT GIVEN AGES IN BOYS AND GIRLS

\begin{tabular}{|c|c|c|c|c|c|c|c|c|c|c|c|}
\hline \multicolumn{4}{|c|}{ Subject } & Weeks & $\begin{array}{c}13 \\
\text { Weeks }\end{array}$ & $\begin{array}{c}26 \\
\text { Weeks }\end{array}$ & $\begin{array}{c}39 \\
\text { Weeks }\end{array}$ & $\stackrel{1}{\text { Year }}$ & $\underset{\text { Months }}{18}$ & $\stackrel{2}{\text { Years }}$ & $\stackrel{3}{\text { Years }}$ \\
\hline $\begin{array}{c}\text { Boys: } \\
\text { No. } \\
\text { Mean }\end{array}$ & $\ldots$ & $\begin{array}{l}\cdots \\
\cdots\end{array}$ & $\begin{array}{l}\ldots \\
\ldots\end{array}$ & $\begin{array}{r}96 \\
0\end{array}$ & $\begin{array}{r}93 \\
0\end{array}$ & $\begin{array}{l}90 \\
0.4\end{array}$ & ${ }_{25}^{85}$ & $\stackrel{82}{6 \cdot 2}$ & $\begin{array}{l}79 \\
12 \cdot 6\end{array}$ & $\begin{array}{l}59 \\
16 \cdot 3\end{array}$ & $\begin{array}{l}35 \\
19 \cdot 9\end{array}$ \\
\hline $\begin{array}{c}\text { Girls: } \\
\text { No. } \\
\text { Mean }\end{array}$ & $\cdots$ & $\cdots$ & $\begin{array}{l}\cdots \\
\cdots\end{array}$ & $\begin{array}{r}96 \\
0\end{array}$ & $\begin{array}{r}91 \\
0\end{array}$ & $\begin{array}{c}84 \\
0.4\end{array}$ & $\stackrel{76}{3 \cdot 1}$ & $\begin{array}{l}77 \\
6 \cdot 1\end{array}$ & $\begin{array}{l}68 \\
13 \cdot 0\end{array}$ & $\begin{array}{l}57 \\
16 \cdot 3\end{array}$ & $\begin{array}{l}30 \\
20 \cdot 1\end{array}$ \\
\hline $\begin{array}{c}\text { Boys and } G \\
\text { No. } \\
\text { Mean } \\
\text { 5th p. } \\
\text { 95th p. }\end{array}$ & $\begin{array}{l}\text { Girls: } \\
\ldots \\
\ldots \\
\end{array}$ & $\begin{array}{l}\cdots \\
\cdots \\
\cdots\end{array}$ & $\begin{array}{l}\cdots \\
\cdots \\
\cdots\end{array}$ & $\begin{array}{r}192 \\
0 \\
-\end{array}$ & $\begin{array}{r}184 \\
0 \\
-\end{array}$ & $\begin{array}{c}174 \\
0 \cdot 4 \\
0 \\
2 \cdot 8\end{array}$ & $\begin{array}{r}161 \\
2 \cdot 8 \\
0 \cdot 2 \\
7 \cdot 7\end{array}$ & $\begin{array}{r}159 \\
6 \cdot 1 \\
2 \cdot 3 \\
9 \cdot 7\end{array}$ & $\begin{array}{r}147 \\
12 \cdot 9 \\
7 \cdot 0 \\
16 \cdot 0\end{array}$ & $\begin{array}{r}116 \\
16 \cdot 3 \\
12 \cdot 9 \\
20 \cdot 6\end{array}$ & $\begin{array}{l}65 \\
20 \cdot 0 \\
20 \cdot 0 \\
21 \cdot 0\end{array}$ \\
\hline
\end{tabular}


TABLE 2

MEAN INCREMENTS OF TEETH ERUPTED IN 13-WEEK PERIODS

\begin{tabular}{|c|c|c|c|c|c|c|c|c|}
\hline & & $\begin{array}{c}\text { 4-13 } \\
\text { Weeks } \dagger\end{array}$ & $\begin{array}{r}13-26 \\
\text { Weeks }\end{array}$ & $\begin{array}{r}26-39 \\
\text { Weeks }\end{array}$ & $\begin{array}{l}39 \text { Weeks- } \\
\text { One Year }\end{array}$ & 18 Months $†$ & 18 Months- & $\frac{2-3}{\text { Yearst }}$ \\
\hline $\begin{array}{l}\text { Boys: } \\
\text { No. } \\
\text { Mean increment } \\
\text { S.D.* }\end{array}$ & $\begin{array}{l}\cdots \\
\cdots \\
\cdots\end{array}$ & $\begin{array}{r}92 \\
0 \\
-\end{array}$ & $\begin{array}{l}86 \\
0 \cdot 3 \\
0 \cdot 8\end{array}$ & $\begin{array}{r}79 \\
2 \cdot 0 \\
1 \cdot 7\end{array}$ & $\begin{array}{r}74 \\
3 \cdot 7 \\
2 \cdot 1\end{array}$ & $\begin{array}{l}65 \\
3 \cdot 0 \\
1 \cdot 2\end{array}$ & $\begin{array}{l}56 \\
1 \cdot 9 \\
1 \cdot 3\end{array}$ & $\begin{array}{l}31 \\
1 \cdot 0 \\
0 \cdot 5\end{array}$ \\
\hline $\begin{array}{l}\text { Girls: } \\
\text { No. } \because \text {. . } \\
\text { Mean increment } \\
\text { S.D. } \ldots\end{array}$ & $\begin{array}{l}\cdots \\
\cdots \\
\cdots\end{array}$ & $\begin{array}{r}91 \\
0 \\
-\end{array}$ & $\begin{array}{l}83 \\
0 \cdot 3 \\
0 \cdot 7\end{array}$ & $\begin{array}{r}70 \\
2 \cdot 7 \\
2 \cdot 0\end{array}$ & $\begin{array}{l}68 \\
2 \cdot 9 \\
1 \cdot 7\end{array}$ & $\begin{array}{l}58 \\
3 \cdot 4 \\
1 \cdot 2\end{array}$ & $\begin{array}{r}49 \\
1 \cdot 5 \\
1 \cdot 0\end{array}$ & $\begin{array}{l}29 \\
1 \cdot 0 \\
0 \cdot 9\end{array}$ \\
\hline $\begin{array}{l}\text { Boys and Girls: } \\
\text { No. . } \quad \text {. } \\
\text { Mean increment } \\
\text { S.D. . . . }\end{array}$ & $\begin{array}{l}\cdots \\
\cdots\end{array}$ & $\begin{array}{r}183 \\
0 \\
\end{array}$ & $\begin{array}{r}169 \\
0 \cdot 3 \\
0 \cdot 8\end{array}$ & $\begin{array}{r}149 \\
2 \cdot 4 \\
1 \cdot 9\end{array}$ & $\begin{array}{r}142 \\
3 \cdot 3 \\
2 \cdot 0\end{array}$ & $\begin{array}{r}123 \\
3 \cdot 2 \\
1 \cdot 1\end{array}$ & $\begin{array}{r}105 \\
1 \cdot 7 \\
1 \cdot 2\end{array}$ & $\begin{array}{l}60 \\
1 \cdot 0 \\
0 \cdot 7\end{array}$ \\
\hline
\end{tabular}

* Standard deviation

teeth is much more regular and although skewed to the left, the figures are probably fairly normally distributed.

Fig. 1 shows graphically the data from Tables 1 and 2. The fifth and 95th percentiles are given. Children falling outside this band may be suspected of being abnormal in this respect. The percentiles here are those of the total group, boys and girls, for the two sexes so clearly approximate each other as can be readily seen.

\section{Pattern of Eruption}

There is a wide range of variation in the number of erupted teeth present at the various ages. The most active period of tooth eruption is between 9 and 18 months.

Table 3 shows the numbers of children erupting their first deciduous tooth in the periods listed.

These children had no teeth present at the beginning of the incremental period, but had developed one or more when seen at the end of the incremental period.

No child examined had any teeth at 4 or 13 weeks, while three boys erupted their first tooth between 1 year and 18 months. No girl was as late as this and no children had failed to erupt at least one tooth by 18 months.

Regarding the completion of deciduous dentition, Table 4 shows the percentages of the children $\dagger$ Adjusted increments

examined at these ages who had completed deciduous dentition.

TABLE 4

PERCENTAGE OF CHILDREN COMPLETING DECIDUOUS DENTITION

\begin{tabular}{c|c|c}
\hline Age (yr.) & Boys (\%) & Girls (\%) \\
\hline 2 & $11 \cdot 8$ & $10 \cdot 5$ \\
3 & 100.0 & 100.0 \\
\hline
\end{tabular}

\section{Sex Differences}

Robinow et al. (1942) found that boys were less variable in the pattern of deciduous tooth eruption and were in advance of the girls in all teeth except the first molar. Meredith (1946) demonstrated a tendency for the process in boys to be two weeks in advance of girls, and Doering and Allen (1942) that, althought not statistically significant, on the average males consistently have more deciduous teeth at every age except 3 years. MacKay and Martin (1952), studying small groups of African children at three-monthly intervals, also found the male consistently, if slightly, in advance of the female.

Comparing means of total teeth erupted of the London children does not show that there is any significant difference between the sexes, and the small spaced time intervals of the examination on the same children do not show any consistent advance of means of one sex over the other. Similarly, no significant difference in the sexes were

TABLE 3

NUMBERS OF CHILDREN ERUPTING THEIR FIRST DECIDUOUS TOOTH

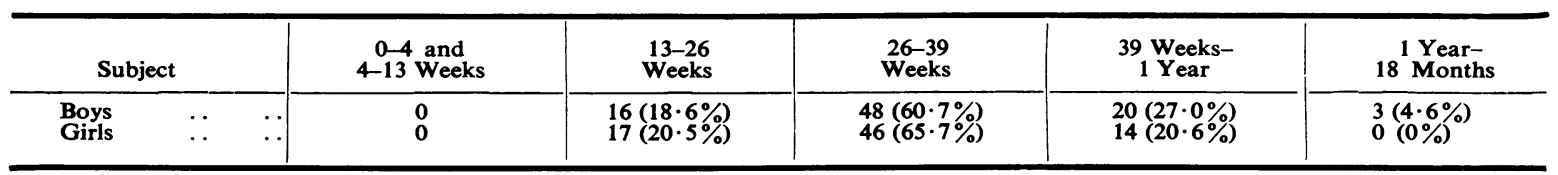

Note - The percentages given are of the number of children actually seen at the end of each incremental period (Each child may not be present for each appointed examination. Hence, the percentages will not total $100 \%$.) 
found in a recent comparative study including four 1928a and b; Steggerda and Hill, 1942; Suk, 1919; European samples and one African sample of children (Falkner, Habich, Pernot and Sénécal,

Palmer, Klein and Kramer, 1938), and related to some extent to other morphological processes, including

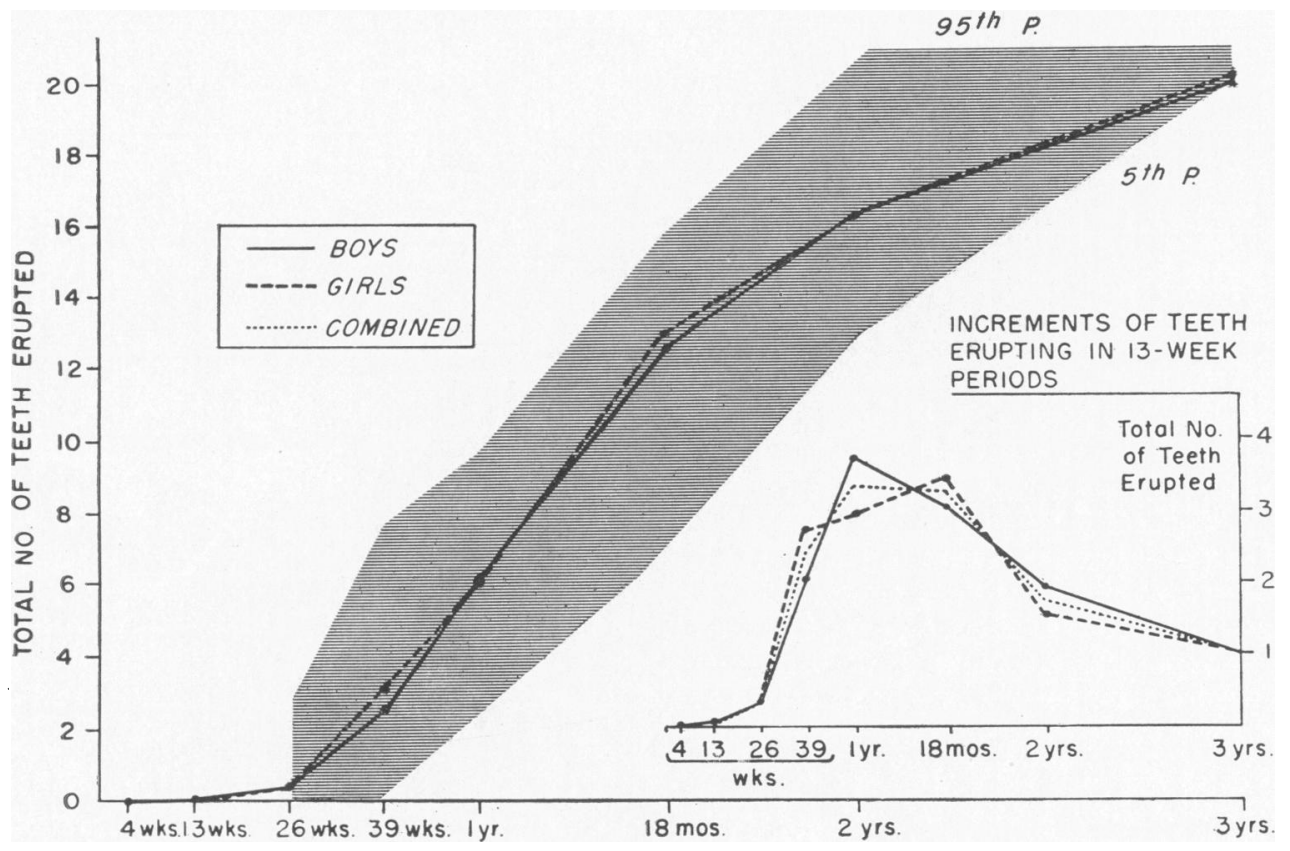

FIG. 1.-The distance and velocity curves of deciduous tooth eruption.

1957). Comparison of early and late eruptors in both sexes showed no trend or significant difference between the sexes.

\section{Deciduous and Permanent Dentition}

Parfitt (1954) has described the age of shedding of deciduous and permanent teeth, and, as he points out, the age of eruption of the permanent teeth may be affected by early shedding of deciduous teeth. Although rare, deciduous teeth are shed in the age range described here. One tooth was shed from each child, and in two children, one tooth each was extracted after injury. These children have been excluded from this series. In this group one child had one permanent tooth at 3 years, while one had two at 3 years.

It is clear that permanent dentition investigated in a wide variety of races is a maturational indicator (Hurme, 1949; Boas, 1933; Clements, DaviesThomas and Pickett, 1953; Cattell, sexual maturity (Tanner, 1955), and that here girls are in advance of boys. There is a particular spurt of eruption in girls around 9 years of age (Suk, 1919), presumably related to the near-puberty state. These children will be followed to test this hypothesis, and it will be interesting to see if deciduous

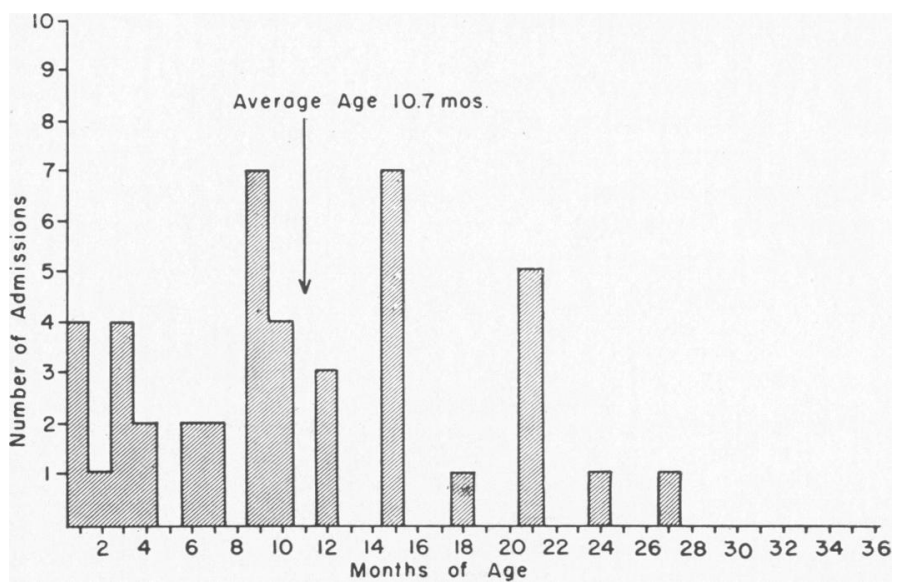

FIG. 2.-Histogram showing ages at which the children were admitted to hospital (see page 391). 
TABLE 5

MEAN LYING-LENGTH OF ADVANCED ERUPTORS (BOYS AND GIRLS COMBINED) AND TOTAL GROUP (BOYS AND GIRLS COMBINED) IN CM. (TO THE NEAREST $0 \cdot 1$ CM.) AT INDICATED AGES

\begin{tabular}{|c|c|c|c|c|c|c|c|c|}
\hline & $\begin{array}{c}4 \\
\text { Weeks }\end{array}$ & $\begin{array}{c}13 \\
\text { Weeks }\end{array}$ & $\begin{array}{c}26 \\
\text { Weeks }\end{array}$ & $\begin{array}{c}39 \\
\text { Weeks }\end{array}$ & $\stackrel{1}{\text { Year }}$ & $\stackrel{18}{\text { Months }}$ & ${ }_{\text {Years }}^{2}$ & $\stackrel{3}{\text { Years }}$ \\
\hline Advanced eruptors & $\begin{array}{c}(9) \\
51 \cdot 7\end{array}$ & $\begin{array}{c}(9) \\
58 \cdot 4\end{array}$ & $\stackrel{(9)}{65 \cdot 0}$ & $\begin{array}{c}(9) \\
68 \cdot 6\end{array}$ & $\begin{array}{c}(8) \\
73 \cdot 0\end{array}$ & $\begin{array}{c}(7) \\
78 \cdot 7\end{array}$ & $\begin{array}{c}(9) \\
82 \cdot 7\end{array}$ & $\begin{array}{c}(7) \\
90 \cdot 7\end{array}$ \\
\hline Rest of total group & $\begin{array}{l}53 \cdot 3 \\
(150)\end{array}$ & $\begin{array}{l}59 \cdot 3 \\
(172)\end{array}$ & $\begin{array}{l}65 \cdot 8 \\
(166)\end{array}$ & $\begin{array}{l}70 \cdot 5 \\
(153)\end{array}$ & $\begin{array}{l}74 \cdot 2 \\
(150)\end{array}$ & $\begin{array}{l}80 \cdot 6 \\
(136)\end{array}$ & $\begin{array}{l}85 \cdot 7 \\
(100)\end{array}$ & $\begin{array}{l}94 \cdot 7 \\
(142)\end{array}$ \\
\hline$\ldots \quad \ldots$ & $<.02>\cdot 01$ & $<\cdot 2>\cdot 1$ & $<\cdot 6>\cdot 5$ & $<\cdot 05>\cdot 02$ & $<\cdot 3>\cdot 2$ & $<\cdot 001$ & $<.02>.01$ & $<\cdot 05>\cdot 02$ \\
\hline
\end{tabular}

* Figures in brackets indicate number examined at each age. ' $P$ ' figures shown for each age, were computed by the ' $t$ ' test.

dentition is in fact 'separate' from permanent dentition in this respect; for if this hypothesis is correct the advance of one sex over the other is reversed, or makes its appearance (if in fact there is no difference in sexes in the deciduous period) at the completion of deciduous dentition. It has not been shown to date whether the two processes of dentition are related in any way. Kihlberg and Koski (1954) argue that if both deciduous and permanent eruption curves are stabilized by the use of logarithms and post-conceptional age, then both processes follow the same biological laws and there is little difference in the sexes.

\section{Maturation}

Tanner (1955), reviewing data (Spier, 1918; Wallis, 1931; Shuttleworth, 1937, 1939), has shown that permanent dentition is clearly to some extent positively related to morphological advancement as indicated by skeletal maturity and height but it is not a strong relationship.

Hellman $(1923,1930)$ in fact states that tall children erupt their permanent teeth later. Table 5 shows comparative figures between the two groups of children in this study, the 'advanced tooth eruptors' and the rest of the sample excluding these children.

The 'advanced eruptors' were selected by virtue of being the only children who had all their deciduous teeth by 2 years. There were 10 'advanced' children, six girls and four boys. Two had all their deciduous teeth by 18 months and eight had all by 2 years.
These 'advanced' children are consistently smaller, as indicated by their lying-length, at each age. By inspection of the data at each age it can be seen that they are highly significantly so at 18 months; at 4 weeks and 2 years, and less so at 3 years and 39 weeks. Clearly smaller babies (by lying-length estimation in this sample) erupt their deciduous teeth at a more rapid rate. It is known that on average by studies on the older child (Bayley, 1943, 1956; Acheson and Hewitt, 1954, etc.) children shorter than the average at particular ages reach their puberty later. It is interesting, therefore, that these children are advanced in deciduous tooth eruption which might have been supposed to be a maturational factor. With this in mind the skeletal maturity of the 'advanced eruptors' was assessed by the method of Acheson (1954) which allows of an adequate measure of this factor (Falkner, 1957b). Since girls are well in advance of boys in this pattern of development it was necessary to separate the sexes, and, although in nearly every case the advanced eruptors were delayed in skeletal maturation compared to the rest of the sample, no definite conclusions could be drawn.

Since Acheson and Hewitt (1954) have shown that retardation in skeletal status is correlated in some measure to a like retardation in height, a very necessary step was to determine if there were any correlation between skeletal maturity and deciduous dentition as a whole. Correlation coefficients of from +0.03 to +0.07 were found at all ages and with the sexes separated showing no relationship between

TABLE 6

MEAN NUMBER OF TOTAL ERUPTED TEETH AT GIVEN AGES (BOYS AND GIRLS COMBINED)

\begin{tabular}{|c|c|c|c|c|c|c|}
\hline Age & $\begin{array}{l}\text { U.S.A. } \\
\text { (Doering and Allen, } \\
1942)\end{array}$ & $\begin{array}{l}\text { U.S.A. } \\
\text { (Meredith, } \\
1951 \text { a \& b) }\end{array}$ & $\begin{array}{c}\text { London } \\
\text { (1957) }\end{array}$ & $\begin{array}{l}\text { Paris } \\
\text { (1957) }\end{array}$ & $\begin{array}{r}\text { Zurich } \\
\text { (1957) }\end{array}$ & $\begin{array}{l}\text { Dakar } \\
\text { (1957) }\end{array}$ \\
\hline 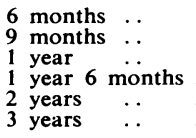 & $\begin{array}{r}0 \cdot 4 \\
3 \cdot 1 \\
5 \cdot 9 \\
12 \cdot 4 \\
16 \cdot 7 \\
19 \cdot 9\end{array}$ & $\begin{array}{r}-3 \\
6 \\
13 \\
17 \\
20\end{array}$ & $\begin{array}{r}0 \cdot 4 \\
2 \cdot 8 \\
6 \cdot 1 \\
12 \cdot 9 \\
16 \cdot 3 \\
20 \cdot 0\end{array}$ & $\begin{array}{r}0 \cdot 4 \\
2 \cdot 9 \\
5 \cdot 8 \\
12 \cdot 3 \\
16 \cdot 4 \\
-\end{array}$ & $\begin{array}{r}0 \cdot 4 \\
2 \cdot 5 \\
5 \cdot 4 \\
12 \cdot 2 \\
16 \cdot 3 \\
-\end{array}$ & $\begin{array}{c}\overline{2 \cdot 7} \\
4 \cdot 7 \\
11 \cdot 4 \\
16 \cdot 4 \\
-\end{array}$ \\
\hline
\end{tabular}


these two processes. Perhaps this is not so surprising since bone is derived from mesoderm, and the teeth, in part, are epithelial.

\section{Race}

Table 6 shows the comparative means of total teeth erupted from six sources (Doering and Allen, 1942; Meredith, 1951a \& b; Falkner et al., 1957).

It is not very surprising how similar the means are for American and European children, but perhaps it is so in the case of African children from Dakar. Steggerda and Hill (1942) found there were racial differences in the permanent tooth eruption patterns and that in a study of four races, Navajo, Negro, Maya and White were advanced over the other in that order. Garn and Moorrees (1951) showed that permanent tooth eruption was markedly advanced in Aleutian Aleuts over white children. Evidence is accumulating that the African child is in advance of the European in many phases of development in early life (Dean, 1956; Falkner et al., 1957, etc.), and Allbrook (1956) has shown that there is a reduction in the adrenal cortical mass in the East African compared to the European, and such work stimulates speculation on the basis for these differing patterns. Again, potential malnutrition might have been expected to delay the African child's deciduous dentition. Since practically all these African children have access to excess quantities of breast milk, it is unlikely that malnutrition will develop early enough to affect deciduous dentition nor incidentally other developmental factors (Sénécal, 1956; Falkner et al., 1957). On the other hand poor maternal prenatal nutrition might have been thought to affect this pattern.

Data on siblings (Robinow et al., 1942) and twins (Tisserand-Perrier, 1953) show that the deciduous eruption pattern is largely influenced by hereditary factors. The genetic element in racial characteristics is of course very large. Further work is needed on this subject.
Here the similarity of means bears out the growing evidence accumulated in this paper and previously (Robinow et al., 1942) that deciduous dentition appears nonchalantly independent of most usually correlated developmental processes.

\section{Illness}

In trying to assess the effect of illness on morphological processes there is the great difficulty in defining what is an illness, and further to rate its severity. In estimating whether the traditional belief that illness retards deciduous dentition was true or false, an alternative method was followed which obviates some of the difficulties mentioned.

In the total sample, 37 children were in hospital in the period of their first three years of life, and none of the others were. Seven were in hospital twice, but no child more than this. There were, therefore, 44 hospital admissions. All the admissions were to a teaching children's hospital, to one of the two isolation hospitals, or to a special unit of a teaching hospital for a specific treatment. Beds for admission of children under 3 years are limited at the children's hospital mentioned by two factors: pressure on beds available; and a very laudable unwillingness of the responsible admitting physicians to take in any child unless really necessary. This applies also to the isolation hospitals. Therefore, it is claimed, fairly one would think, that any child being in hospital in this period was ill to a reasonably and comparatively severe degree. Having been admitted they then were under the influences of their disease and hospital life per se.

Table 7 shows the state of deciduous eruption of the two groups: children who had been in hospital; and the rest of the sample who had not.

The children who had been in hospital up to and including 1 year of age had always fewer teeth than those not admitted. This difference was significant at 26,39 weeks and 1 year of age with boys and girls

MEANS OF TOTAL ERUPTED TEETH IN CHILDREN ADMITTED AND NOT ADMITTED TO HOSPITAL (BOYS AND GIRLS, AND SEXES COMBINED)

\begin{tabular}{|c|c|c|c|c|c|}
\hline & & & Admitted to Hospital & Not Admitted & $\mathbf{P}$ \\
\hline $\begin{array}{l}\text { Boys: } 26 \text { weeks } \ldots \\
\text { Girls: } 26 \text { weeks } \because \\
\text { Boys and Girls: } 26 \text { weeks }\end{array}$ & $\begin{array}{l}\cdots \\
\cdots \\
\cdots\end{array}$ & $\begin{array}{c}\cdots \\
\cdots \\
\cdots\end{array}$ & $\begin{array}{l}0 \cdot 2(19) \\
0 \cdot 3(13) \\
0 \cdot 2(32)\end{array}$ & $\begin{array}{l}0 \cdot 5(71) \\
0 \cdot 4(71) \\
0 \cdot 5(142)\end{array}$ & $\begin{array}{l}\cdot 05 \\
>\cdot 7 \\
<\cdot 1>\cdot 05\end{array}$ \\
\hline $\begin{array}{l}\text { Boys: } 39 \text { weeks } \ldots \\
\text { Girls: } 39 \text { weeks } . \\
\text { Boys and Girls: } 39 \text { weeks }\end{array}$ & $\cdots$ & $\begin{array}{l}\cdots \\
\cdots \\
\cdots\end{array}$ & $\begin{array}{l}1 \cdot 7(16) \\
2 \cdot 5(13) \\
2 \cdot 1(29)\end{array}$ & $\begin{array}{l}2 \cdot 6(69) \\
3 \cdot 2(63) \\
2 \cdot 9(132)\end{array}$ & $\begin{array}{l}<\cdot 2>\cdot 1 \\
<\cdot 3>\cdot 2 \\
<\cdot 2>\cdot 05\end{array}$ \\
\hline $\begin{array}{l}\text { Boys: } 1 \text { year } \\
\text { Girls: } 1 \text { year } \\
\text { Boys and Girls: } 1 \text { year }\end{array}$ & $\begin{array}{l}\cdots \\
\cdots \\
\cdots\end{array}$ & $\begin{array}{l}\cdots \\
\cdots \\
\cdots\end{array}$ & $\begin{array}{l}5 \cdot 5(18) \\
4 \cdot 4(12) \\
5 \cdot 4(30)\end{array}$ & $\begin{array}{l}6 \cdot 2(64) \\
6 \cdot 2(65) \\
6 \cdot 2(129)\end{array}$ & $\begin{array}{l}<\cdot 4>\cdot 3 \\
<\cdot 2>\cdot 1 \\
<\cdot 01\end{array}$ \\
\hline
\end{tabular}

* Figures in brackets are numbers of children involved. ' $t$ ' Test computed and ' $P$ ' figures given up to one year. 
combined and for the boys alone at 26 weeks. There was no trend and no significant difference after 1 year of age. Fig. 2 shows a histogram of the hospital admissions and demonstrates their timing. The average age at time of admission was $10 \cdot 7$ months and indicates a possible cause and effect value between admission to hospital and retardation of deciduous eruption.

Traditional teaching in the lecture hall and some investigators (Robinow, 1942) have sometimes indicated that acute illness softens the gums and hence increases the rate of deciduous teeth eruption. This would appear to be false.

\section{Summary}

Means of total erupted deciduous teeth present are given at ages of $4,13,26,39$ weeks, 1 year, 18 months, 2 and 3 years in a sample of children longitudinally followed. The fifth and 95th percentiles are given.

The means and standard deviations of increments of erupting teeth are given between the ages stated above.

The distribution curves of total teeth present are discussed and shown to be abnormally distributed. Those of incremental data are nearly normally so.

The general pattern of eruption is discussed in the sexes both from the point of view of the value of deciduous eruption as a maturational indicator and of its relationship to skeletal maturation. It appears that deciduous dentition is remarkably independent of other morphological processes.

In this sample children advanced in deciduous tooth eruption are consistently and significantly smaller than the average during eruption. No relationship is shown between deciduous tooth eruption and skeletal maturation.

Comparisons of deciduous dentition are made between American, European and African children. There is a markedly similar pattern.

It is suggested that the effect of admission to hospital and presumably illness of some severity slows deciduous dentition.

I am much indebted to Professor Alan Moncrieff for constant encouragement; to Drs. Stanley M. Garn and Kalevi Koski for advice and criticism; to Miss Coral Tibbetts and Mr. Richard Westland for computational assistance; and to Mrs. Nancy Singleton for secretarial help.

\section{REFERENCES}

Acheson, R. M. (1954). J. Anat. (Lond.), 88, 498.

and Hewitt, D. (1954). Brit. J. prev. soc. Med., 8, 59.

Allbrook, D. (1956). Lancet, 2, 606.

Bayley, N. (1943). Child Developm., 14, 1.

(1956). J. Pediat., 48, 187.

Boas, F. (1927). J. dent. Res., 7, 245.

Cat (1933). Hum. Biol., 5, 429.

Cattell, P. (1928a). J. dent. Res. 8, 279.

(1928b). Dentition as a Measure of Maturity. Cambridge, Mass.

Clements, E. M. B., Davies-Thomas, E. and Pickett, K. G. (1953). Brit. med. J., 1, 1425.

Dean, R. F. A. (1956). Conference on the Role of Body Measurements in the Evaluation of Human Nutrition, Cambridge, Mass., 1955. (National Research Council.) Reported in Hum. Biol., 28, 252 (1956).

Doering, C. R. and Allen, M. F. (1942). Child Developm., 13, 113.

Falkner, F. (1955). Ed. Une Base-Commune de Récherches pour les Etudes Longitudinales sur la croissance de l'Enfant. Centre Int. de l'Enfance, Paris.

(1957a). Ed. Internationally Cooperative Research in Child Development. (In French and English.) Centre Int. de l'Enfance, Paris. (In the Press.)

(1957b). Proceedings Amer. Ass. Phys. Anthrop. Amer. J. Phys. Anthrop., 14, No 2. (In the Press.)

-, Habich, H., Përnot, M. and Sénécal, J. (1957). International Comparisons of Growth in First Two Years of Life. Courrier. CIE Paris. (In the Press.)

Garn, S. M. and Moorrees, C. F. A. (1951). Child Developm., 22, 261

Hellman, M. (1923). Dent. Cosm., 65, 34 and 1329.

(1930). White House Conference on Development of Children, Vol. II, p. 149 .

Hurme, V. O. (1949). J. dent. Child., 16, no. 2, p. 11.

Kihlberg, J. and Koski, K. (1954). Suom. Hammaslaak. Toim., 50,

MacKay, D. H. and Martin, W. J. (1952). J. trop. Med. Hyg., 55,265

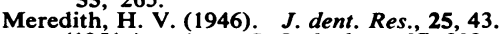

(1951 a). Amer. J. Orthodont., 37, 802

- (1951b). J. Pediat., 38, 482.

Moore, T., Hindley, C. B. and Falkner, F. (1954). Brit. med. J., 2,1132 .

Palmer, C. E. Klein, H and Kramer, M. (1938). Growth, 2, 149.

Parfitt, G. J. (1954). Dent. Rec., 74, 279.

Robinow, M., Richards, T. W. and Anderson, M. (1942), Growth, $6,127$.

Sénécal, J. (1956). Personal Communication.

Shuttleworth, F. K. (1937). Monogr. Soc. Res. Child Dev., 2. No. 5. - (1939). Ibid., 4, No. 3.

Spier, L. (1918). Dent. Cosm., 60, 899.

Steggerda, M. and Hill, T. J. (1942). Amer. J. Orthodont., 28, 361.

Suk, V. (1919). Amer. J. phys. Anthrop., 2, 351.

Tanner, J. M. (1955). Growth at Adolescence. Oxford.

Tisserand-Perrier, M. (1953). J. Génét. hum., 2, 87.

Wallis, R. S. (1931). Univ. of Iowa Stud. Child Welfare, 5, No. 1. 